\section{Internationalize American Higher Education? Not Exactly}

\section{Philip G. Altbach and Patti McGill Peterson}

Philip G. Altbach is J. Donald Monan SJ professor of higher education and director of the Center for International Higher Education at Boston College. Patti McGill Peterson is executive director of the Council on International Exchange of Scholars (Fulbright Program) and vice president of the Institute of International Education. Address: CIES, 3007 Tilden Place NW, Washington DC 20008, USA. Fax: 202/362-3184.

We are on the verge of a global century, and internationalism is in the air on American campuses. Everyone agrees that American students must be prepared for the global environment of the 21 st century. No presidential speech or campus planning report fails to stress the importance of internationalizing the university. Institutions proclaim various international initiatives. These include instruction in "nontraditional" languages (such as Japanese, Arabic, or even Kiswahili), expansion of study abroad programs, and strengthening international and area studies in the curriculum.

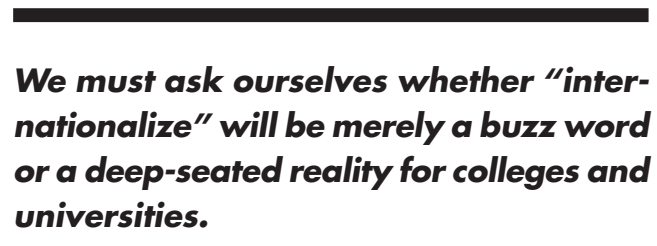

But let's look behind the rhetoric. We must ask ourselves whether "internationalize" will be merely a buzz word or a deep-seated reality for colleges and universities. In fact, there are significant constraints in the internationalization of American higher education. In an era of budget cutting, most colleges and universities lack adequate financial resources for major international initiatives. And institutions with a lot of international activity on campus often lack a coherent strategic direction for these activities that would provide the connective tissue among them. For example, how does the goal to have more students study abroad relate to plans for faculty development? Will we have a globally oriented student body being taught by a faculty that is hard pressed to find funds to support opportunities to place their teaching and research in a comparative context? Will foreign students on U.S. campuses be seen as sources of income or as valuable resources of international expertise and experience?

One indication of the lack of a clear strategy is the current debate about "globalism" versus "area studies."
Advocates of a global approach to training academic specialists, led by the Social Science Research Council, are opposed by experts who argue that in order to understand another culture it is necessary to know its history, language, economy, and culture and not just global issues and trends. This debate has implications for scholarship, library resources, and the entire approach to the training of academic specialists. Rather than forcing a Solomon's solution, this debate needs leadership to foster a creative and reinforcing synthesis among the alternatives.

\section{The lack of a national approach to in- ternational education may increasingly place the United States in an isolated position.}

Just as importantly, the need to provide more international dimensions for American higher education has not been elevated to the status of a national challenge. With the Cold War over and the lack of a perceived external threat, the sense that we have to gear up our educational resources to confront something beyond our borders is missing. No Sputnik lights up the sky to warn policymakers that educational institutions need to be ready to help the United States play its part in a global era. Funds earmarked by the federal government for international educational efforts have diminished dramatically, and there is no compelling lobby from the higher education community arguing for the restoration of funding. For example, when the Fulbright Program, the flagship of U.S. sponsored scholarly exchange programs, was cut by 20 percent several years ago, no hue and cry arose from the academic community. We need to define more carefully the role of the federal government in addressing the international challenge. What kind of partnership between higher education institutions and the government is desirable and appropriate in preparation for the global imperatives that face us? Neither party really seems to be dealing with these issues in a comprehensive fashion.

The lack of a national approach to international education may increasingly place the United States in an isolated position. Japan, more than a decade ago, committed itself to hosting 100,000 international students by the year 2000. This policy created a variety of initiatives at the national level as well as in many universities, and it stressed international education as a national goal. Even though Japan will likely fall short of its goal, the initiative put interna- 
tional education on the agenda. Through programs such as ERASMUS and SOCRATES, a variety of regulations aimed at "harmonizing" higher education arrangements among European Union members, and the investment of considerable funds, the EU has also stressed the internationalization of higher education as a policy. The United States has basically been silent on the national importance of internationalizing higher education. It is noteworthy that our major trade treaty, NAFTA, has no stated education component. By contrast, European Union economic cooperation focuses considerable attention on education, science, and culture, and it provides the funds necessary to ensure that programs will be successful. The lack of national focus on international education as a priority could mean that the United States will fall behind its competition in this key area.

The faculty also lacks both international consciousness and international involvement.

The weakness in policy and strategic decisions affecting higher education can be most readily discerned on issues involving students and faculty. For example, the role of international students on American college and university campuses is unclear. Some see them as "cash cows" who fill empty seats and help to balance precarious budgets. Others view these students as valuable resources for internationalizing the campus. Some universities actively recruit overseas, while others do not. Public colleges and universities charge international students "out-of-state" tuition rates, and many private institutions exclude international students from financial aid programs. The recent financial crisis in Asia and the hardship it has imposed on many Asian students studying in the United States should prompt a reexamination of the financial aid issue. At present 67 percent of international students are self- or family-supported. What are the implications of this statistic if we wish to have more international students on our campuses as part of a larger plan to internationalize our institutions?

National immigration policies further complicate this situation. The recent tightening of immigration regulations and the imposition of high fees for visas have created serious problems for international students. Such impediments do not bode well for the future of international students in the United States.
Although the United States remains the largest host nation for international students, with 457,984 studying here in 1996-97, growth has slowed to under 1 percent. With the Asian economic crisis, the numbers will probably decline next year for the first time in a half century because well over half of the international students in the United States come from Asia. Large numbers come from countries hardest hit by the crisis-South Korea, Thailand, and Indonesia.

While the numbers of American students going abroad to study continues to increase-although at a more modest level this year-only 89,742 out of 14 million U.S. students studied abroad in 1996-1997, an infinitesimal .06 percent. Further, more than half studied abroad for a semester or less and only 12 percent for a full academic year. The majority, 65 percent, studied in Europe, while 15 percent studied in Latin America, 8 percent in Asia, and a scant 2 percent in Africa. Clearly the number of students studying abroad and their distribution among the regions of the world do not support the proposition that we are internationalizing this aspect of American higher education. Nor do levels of foreign language study in our colleges and universities give rise to such a claim. Enrollments have been in a continuing slump, although there has been growth in such languages as Chinese, Japanese, and Arabic-but from an extraordinarily low base. Very few students graduate with fluency in another language. Increasingly, students are permitted to study abroad with no language proficiency. This trend contributes to a growing image in many countries that American students are not there for studies but for extended tourism.

\section{The lack of national focus on inter- national education as a priority could mean that the United States will fall behind its competition in this key area.}

Students represent only a part of the problem. The faculty also lacks both international consciousness and international involvement. A surprising finding from the 14-nation Carnegie Foundation study of the international academic profession was that American faculty, alone among the 14 countries, was largely uncommitted to internationalism. While 90 percent of the faculty in 13 countries believe that a 
scholar must read books and journals from abroad to keep up with scholarly developments, only 62 percent of Americans believe this. Upwards of 80 percent of the faculty in 13 countries value connections with scholars in other countries. A little over half the American professoriate are in agreement. American faculty are similarly indifferent about further internationalizing the curriculum, with only 45 percent agreeing that this should be done. The large majority of American faculty report no foreign trips for study or research in the last three years. Americans scored last among the 14 countries in overseas travel and research. By every possible measure, American faculty score below their foreign colleagues on internationalism.

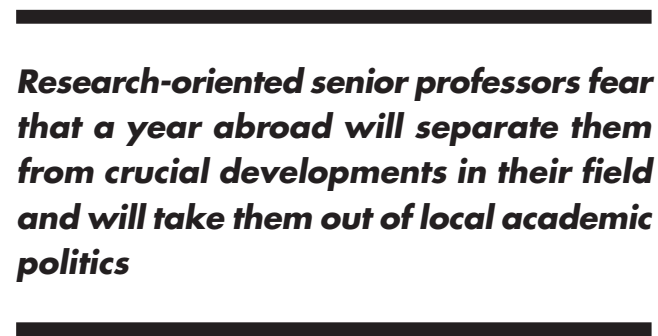

There are many reasons for this phenomenonamong them the poor preparation of Americans in foreign languages, and a feeling that the United States is in any case the world center of science and scholarship. American academics express a greater commitment to teaching than do faculty overseas, and, with the exception of faculty at the selective liberal arts colleges, professors with a teaching orientation tend to be less internationally minded, according to the Carnegie statistics. Structural factors also inhibit American faculty. Younger scholars sometimes refuse to take Fulbright grants because they believe that a stint overseas will harm their chances for tenure. Research-oriented senior professors fear that a year abroad will separate them from crucial developments in their field and will take them out of local academic politics. International concerns are often interdisciplinary in nature, and academics fear leaving the well-tread paths of the established disciplines and departments. With a few exceptions, academic leaders do not ease the path to international involvement for their faculty. Administrators at colleges and universities need to create incentives to encourage and reward more internationalism among faculty.

America's insularity manifests itself in a number of ways. American faculty may fall behind their col- leagues from other countries in reaching out to the rest of the world but so do members of the United States Congress, one-third of whom do not even possess a passport. In an ironic way, tensions with the Soviet Union during the Cold War made policymakers more conscious of the rest of the world. Now that the conflict is over, one of the results for the United States may be that it has been lulled into a false sense of complacency.

American higher education may be a victim of its own success as well. The strength of higher education in this country is acclaimed throughout the world. Scholars make the academic pilgrimage to the United States based upon the international reputation of the quality of teaching and research in American colleges and universities. Last year, 62,000 scholars from other countries took the opportunity to pursue study and research in the United States. Emblematic of the migration is the fact that English is increasingly the international language of scholarship.

All of this has caused Americans to perceive themselves as being at the center of the academic universe. And to an extent, we are. But we ignore the rest of the world at our own peril. Not only can Americans learn much from research and scholarship taking place elsewhere, but it is mandatory for us to understand the languages, cultures, and ideas as well as the economies of the rest of the world if we are to work effectively in a complex and multipolar world. We can only do this if we study foreign cultures, interact with colleagues in other countries, send our students to study and learn firsthand about the rest of the world, and in the process build up not only expertise, but also goodwill and mutual understanding between the United States and the rest of the world.

\section{Americans can learn much from the re- search and scholarship taking place elsewhere.}

American higher education can lead the way by expecting more from itself and becoming a more articulate and well-organized advocate with the U.S. government on behalf of initiatives that join in partnership with colleges and universities to promote international programs and academic exchange. Doing so will be a clear acknowledgment of the importance of our global relationships as we enter a new century. 